\title{
Time, Queerness and Global Politics
}

Rao, Rahul. 2020. Out of time: The queer politics of postcoloniality. Oxford: Oxford University Press. (280 pages)

DURING STOCKHOLM PRIDE 20I9, the far-right party Sweden Democrats, with a record of opposing all pro-LGBTQ reforms domestically, proposed to cut foreign aid to countries criminalizing same-sex relations. This is an example of how "gay-friendly" narratives displacing homophobia onto racialized, Global South Others are incorporated into nationalism. However, it also shows how queerness functions as a global political signifier, the meaning of which changes across time and space. In nineteenth-century Victorian discourse, the imposition of "modern" heteronormative ideals through colonial sodomy bans was seen as a way to civilize savages. In contrast, in our time, LGBTQ rights are sometimes a marker of being "on the right side of history". Queerness thus switches place in relation to the colonizer/colonized binary and ideas of modernity. For Rahul Rao, this exemplifies how queer politics are structured by time, including memories of the past and imaginations of the future. His new book asks how time matters in the queer postcolony, and specifically how the afterlives of British colonialism in Uganda, India and Britain shape contemporary queer politics. Rao situates his contribution in relation to queer theories on temporality, which have criticized mainstream LGBTQ politics for being attached to an 
evolutionary understanding of time as moving unidirectionally from an oppressive past to an emancipated future. Queer problematizations of rights-gains achieved by progressive movements - summarized by Jasbir Puar in the question "what happens when 'we' get what 'we' want?" (20I7:xviii) - have however, Rao argues, been shaped by US experiences of assimilation into (neo)liberal frameworks. In contexts where queer movements are struggling against criminalization or state persecution, seemingly far from having "gotten what they wanted", the question is whether, and in what ways, concepts such as homonationalism and homonormativity are relevant.

The issue of time and postcolonial queer politics is investigated through case studies focusing on Uganda's Anti-Homosexuality Act (AHA) first proposed in 2009, and Indian queer activists' struggles to abolish the anti-sodomy law and to improve the situation of hijras (often described as India's "third gender"). The analysis draws on fieldwork as well as historical and contemporary texts, including newspapers, films and novels. In the first chapter, Rao problematizes two common narratives in international discussions of Uganda's AHA: the idea that homophobia is rooted in "African tradition" vs the claim that homophobia is a modern Western invention. Rao instead suggests understanding homophobia as not bound to an essentialized culture or place, but as a transnational collaborative endeavor involving Global South and Global North elites. Next, Rao studies contemporary commemoration of the nineteenth-century "Uganda martyrs" and king Mwanga, and the place of the king's alleged queerness in this story. The analysis shows the genealogies of homophobic narratives as well as queer possibilities within public memorialization. In the third chapter, Rao directs attention to the imperial center by studying British parliamentary debates on atonement for colonial anti-sodomy laws. While British elites have channeled their shame over having imposed anti-sodomy laws into moral crusades for global LGBTQ rights, there is no corresponding willingness to atone for Britain's role in slave trade. This difference in dealing with legacies of sexual vis-a-vis racial repression indicates, Rao argues, how these debates are structured by ideas of whiteness. The fourth chapter 
examines the role of global financial institutions in the contestations of Uganda's AHA. Rao describes an international governmentality of "homocapitalism", where homophobia is constructed as an impediment to economic growth. Such a logic understands homophobia as a cultural problem of "outdated" attitudes. It thus makes invisible economy and the role that financial institutions played in creating conditions that enabled the AHA, through "structural adjustment programs" gutting social services and creating holes that were filled by Pentecostal churches. In the final chapter, Rao discusses the 2014 decision by India's Supreme Court to grant trans people recognition as a "backward" class, earning them certain constitutional protections. The Court's decision was modelled on how casteless Dalits had previously been designated "underdeveloped" and thus entitled to affirmative action measures. Rao examines how gender identity and backwardness figure in contemporary Indian nationalism, showing how the narrative of India's transition from developing country to future great power is articulated as a gender transition.

Carefully researched, empirically rich, theoretically innovative and written in an elegant prose, Rao's book is an important and enjoyable read for anyone with an interest in global queer politics. It offers several contributions with implications for research as well as activism and advocacy. First, it convincingly shows how notions of both queerness and time, rather than being fixed in relation to each other, fluctuate and change. Rao lays out how sexuality constitutes a terrain of conflict where queerness becomes a metonym for different things (imperialism or anti-imperialism, modernity or backwardness). Imaginations of the past and the future offer resources for queer struggles as well as anti-queer politics. This calls for open-ended investigations into what functions specific narratives (e.g. universalist human rights rhetoric) perform in different contexts. Secondly, Rao points to the dangers of reading postcolonial queer politics through a reductionist West-centric lens, ignoring the agency of postcolonial elites. He shows the importance of simultaneously looking at (neo)imperialism, the contemporary postcolonial state, and transnational constellations. Third, Rao's discussion of homocapitalism brings in an often overlooked political 
economy perspective in the analysis of global LGBTQ politics. The concept provides a useful starting point for analyzing "pro-LGBTQ" international actors that may not have been complicit in imposing colonial anti-sodomy laws and are cautious not to frame their global advocacy in the terms of a civilizing mission. Nonetheless, such actors may enthusiastically embrace neoliberal reason and the "business case" for LGBTQ acceptance.

Like all good books, Out of time provokes some questions. At the end of most chapters, Rao points to possible alternative ways of deploying memory and futurity in postcolonial queer politics. For example, he discusses how Ugandan queer activists, manifesting solidarity with the victims of the Orlando shooting, disoriented the narrative of Global South queers as solely victims and recipients of Western support. In another chapter he suggests a reclaiming of the memory of the "queer enslaved". These possibilities are hinted at rather than elaborated on, and I found myself wanting to know more about what forms of politics, subjectivities and altered power relations Rao's examples could offer. Another question concerns the implications of Rao's critique for understanding homophobia and queer politics in other contexts such as Russia and Eastern Europe. These locations are usually not considered "postcolonial" and are historically constructed as occupying an in-between position in relation to Western modernity and Oriental backwardness. What temporal meanings can queerness have in relation to populations constructed not as "out of time", but rather as "in transition"? And what forms of politics are thereby made possible and impossible (cf. Kulpa and Mizielinska 20I 2)? Rao's book opens up for these and other conversations. It contributes to a revitalization of queer studies of global politics, and deserves to be widely read and introduced on course curricula. 


\section{REFERENCES}

Kulpa, Robert \& Joanna Mizielinska. 20ı 2. "Guest editors' introduction: Central and Eastern European sexualities 'in transition'”. lambda nordica, I7 (4), I9-29.

Puar, Jasbir. K. 2017. The right to maim: Debility, capacity, disability. Durham: Duke University Press. 